\title{
DOES THE ENGLISH RULE DISCOURAGE LOW-PROBABILITY-OF-PREVAILING PLAINTIFFS?
}

\author{
A. MITCHELL POLINSKY and DANIEL L. RUBINFELD*
}

\begin{abstract}
One of the principal results in the economic theory of litigation is that the English rule of fee allocation (in which the loser pays the winner's litigation costs) is better at discouraging suits by low-probability-of-prevailing plaintiffs than the American rule (in which each side bears its own costs). This result has been demonstrated under the assumption that all suits that are filed go to trial. Using a standard asymmetric-information model of litigation, we show that when the settlement process is taken into account the English rule results in more low-probability-ofprevailing plaintiffs going to trial than the American rule. In this sense, the English rule encourages low-probability plaintiffs more than the American rule.
\end{abstract}

\section{INTRODUCTION}

$\mathrm{O}$ $\mathrm{NE}$ of the principal results in the economic theory of litigation is that the English rule of fee allocation (in which the loser pays the winner's litigation costs) is better at discouraging suits by low-probability-of-prevailing plaintiffs than the American rule (in which each side bears its own costs). ${ }^{1}$

* Polinsky is affiliated with Stanford University and the National Bureau of Economic Research. Rubinfeld is affiliated with the University of California, Berkeley. Polinsky's research was supported by the John M. Olin Program in Law and Economics at the Stanford Law School. Rubinfeld's research was supported by the John Simon Guggenheim Memorial Foundation. We received helpful comments from Lucian Bebchuk, Amy Farmer, Keith Hylton, Christine Jolls, Avery Katz, Daniel Kessler, Thomas Miceli, Paul Pecorino, Steven Shavell, Kathryn Spier, Eric Talley, and an anonymous referee.

1 This result is subsumed in a more general proposition stated by Steven Shavell, Suit, Settlement, and Trial: A Theoretical Analysis under Alternative Methods for the Allocation of Legal Costs, $11 \mathrm{~J}$ Legal Stud 55, 59 (1982): "[T]he frequency of suit will be greater under the British system when the plaintiff believes the likelihood of prevailing is sufficiently high-above a 'critical' level - and the frequency will be greater under the American system when the likelihood is below the critical level" (italics and footnote omitted). The result is stated even more explicitly by David Rosenberg and Steven Shavell, A Model in Which Suits Are Brought for Their Nuisance Value, 5 Intl Rev L \& Econ 3, 5 (1985): “"[U]nder the British system the willingness of the plaintiff to litigate and to file a claim will be less than under the ... American system if the likelihood of prevailing is low" (italics and footnote omitted). In an empirical study of the American and the English rules, James W. Hughes and Edward A. Snyder, Litigation and Settlement under the English and American Rules: Theory and

[Journal of Legal Studies, vol. XXVII (June 1998)]

(†) 1998 by The University of Chicago. All rights reserved. 0047-2530/98/2702-0011\$01.50 
This result has been demonstrated under the assumption that all suits that are filed go to trial. Little attention has been paid to the question of how the rules affect low-probability-of-prevailing plaintiffs when the possibility of settlements is taken into account. Our contribution is to answer this question in a standard asymmetric-information model of litigation. ${ }^{2}$

We show that when the settlement process is taken into account the English rule has a surprising effect-it results in more low-probability-of-

Evidence, 38 J Law \& Econ 225, 249 (1995), conclude that "the English rule likely reduces the frequency of low-merit [low-probability-of-prevailing] claims." Although Avery Katz, The Effect of Frivolous Lawsuits on the Settlement of Litigation, 10 Intl Rev L \& Econ 3, 17-19 (1990), and Lucian Arye Bebchuk and Howard F. Chang, An Analysis of Fee Shifting Based on the Margin of Victory: On Frivolous Suits, Meritorious Suits, and the Role of Rule 11, $25 \mathrm{~J}$ Legal Stud 371, 378-80 (1996), present models of litigation in which the English rule may not be better at discouraging low-probability-of-prevailing plaintiffs, when one makes reasonable empirical judgments about the parameters in their models, their analyses also support the result stated in this article (see notes $10 \& 11$ and the accompanying text). See also Ronald Braeutigam, Bruce Owen, and John Panzar, An Economic Analysis of Alternative Fee Shifting Systems, 47 L \& Contemp Prob 173 (1984).

${ }^{2}$ Although many authors have analyzed how switching from the American rule to the English rule (or some variant of it) affects the incentive to settle and/or the settlement amount, most of them ignore the question at issue here because they do not consider plaintiffs who differ in terms of their probabilities of prevailing. See, for example, Shavell, at 63-69 (cited at note 1); Lucian Arye Bebchuk, Litigation and Settlement under Imperfect Information, 15 RAND J Econ 404 (1984) (discussed further in note 17); Jennifer F. Reinganum and Louis L. Wilde, Settlement, Litigation, and the Allocation of Litigation Costs, 17 RAND J Econ 557 (1986); Ivan P. L. Png, Litigation, Liability, and Incentives for Care, $34 \mathrm{~J}$ Pub Econ 61 , 75-77 (1987); Don L. Coursey and Linda R. Stanley, Pretrial Bargaining Behavior within the Shadow of the Law: Theory and Experimental Evidence, 8 Intl Rev L \& Econ 161 (1988); Hugh S. E. Gravelle, Accidents and the Allocation of Legal Costs with an Uninformed Court, 14 Geneva Papers Risk \& Insur 11 (1989); Hugh S. E. Gravelle, The Efficiency Implications of Cost-Shifting Rules, 13 Intl Rev L \& Econ 3 (1993); John C. Hause, Indemnity, Settlement, and Litigation, or I'll Be Suing You, 18 J Legal Stud 157 (1989); John J. Donohue III, Opting for the British Rule, or If Posner and Shavell Can't Remember the Coase Theorem, Who Will? 104 Harv L Rev 1093 (1991); Keith N. Hylton, Litigation Cost Allocation Rules and Compliance with the Negligence Standard, 22 J Legal Stud 457 (1993); Kathryn E. Spier, Pretrial Bargaining and the Design of Fee-Shifting Rules, 25 RAND J Econ 197 (1994); Eric Talley, Liability-Based Fee-Shifting Rules and Settlement Mechanisms under Incomplete Information, 71 Chi Kent L Rev 461 (1995); and Lucian Arye Bebchuk, The Effect of FeeShifting Rules on Settlement Terms (Discussion Paper No 202, Harv L Sch, John M. Olin Ctr L, Econ, \& Bus, October 1996). The only notable exceptions are Rosenberg and Shavell (cited at note 1); Katz, at 17-19 (cited at note 1); and Amy Farmer and Paul Pecorino, A Reputation for Being a Nuisance: Frivolous Lawsuits and Fee Shifting in a Repeated Play Game (unpublished manuscript, Univ Tenn, Dept Econ, \& Univ Ala, Dept Econ, Finance, \& Legal Stud, August 1996). See also Ivan P. L. Png, Strategic Behavior in Suit, Settlement, and Trial, 14 Bell J Econ 539, 549 (1983). However, none of these articles focus on the question that is central to our analysis-how the settlement process affects the types of plaintiff who go to trial under the American and English rules-or makes the point that we develop here. Also of related interest are two empirical studies: Edward A. Snyder and James W. Hughes, The English Rule for Allocating Legal Costs: Evidence Confronts Theory, $6 \mathrm{~J} \mathrm{~L}$ Econ \& Org 345 (1990); and Hughes and Snyder (cited at note 1). 
prevailing plaintiffs going to trial than the American rule. Stated more precisely, the English rule causes a greater number of cases to go to trial, and all of these additional cases involve plaintiffs whose probability of prevailing is less than that of plaintiffs who go to trial under the American rule. In this sense, the English rule encourages low-probability plaintiffs more than the American rule. ${ }^{3}$

It is important to point out that the conventional result concerns the incentives of parties to file suits, whereas our focus is on the decisions of parties whether to go to trial or to settle. Our conclusion does not contradict the conventional result. Although we show that the English rule leads to more trials involving low-probability plaintiffs, our analysis does not imply that the English rule also causes more suits to be filed by low-probability plaintiffs. In the model we employ, the same suits are filed under the two rules. More generally, it could be the case that the English rule discourages the filing of suits by some low-probability plaintiffs while encouraging other low-probability plaintiffs to go to trial. ${ }^{4}$

The intuition behind the conventional result is well known: Under the English rule, the lower a plaintiff's probability of prevailing, the more likely it is that he will bear not only his own costs at trial but also the defendant's legal costs. Under the American rule, in contrast, he never has to pay the defendant's legal costs. Consequently, there will be some lowprobability plaintiffs who will be deterred from bringing suits under the English rule, but who will sue and go to trial under the American rule.

Now consider the effect of introducing the settlement process into this analysis. We assume that the defendant makes the same settlement offer to all plaintiffs because he does not know each plaintiff's probability of prevailing. Under the American rule, if the settlement offer is positive, there will be a critical probability of prevailing below which plaintiffs will accept the settlement offer and above which they will reject it and go to trial. Suppose for concreteness that this critical probability is .2. Thus, a plaintiff with a probability of prevailing of .2 will be indifferent between accepting the settlement offer and going to trial under the American rule.

Observe, however, that this plaintiff will be worse off at trial under the English rule than under the American rule because, under the English rule, if he goes to trial he will have to pay the defendant's legal costs with a

\footnotetext{
${ }^{3}$ We often will use the expression "low-probability plaintiffs" as a shorthand term for "low-probability-of-prevailing plaintiffs." Moreover, the term "low probability" sometimes will be used in a relative rather than in an absolute sense (for example, a plaintiff whose probability of prevailing is .6 is a low-probability plaintiff compared with a plaintiff whose probability of prevailing is .7).

${ }^{4}$ For further discussion of this point, see comment $b$ in Section V.
} 
probability of $.8 .^{5}$ Therefore, if the settlement offer were the same under both rules, a plaintiff with a probability of prevailing of .2 would strictly prefer to accept the settlement offer under the English rule. Since he was indifferent under the American rule, this implies that the critical probability of prevailing must be higher under the English rule. This in turn means that some low-probability plaintiffs who would have gone to trial under the American rule will be induced to settle under the English rule. Thus, if the settlement offer were the same under the two rules, fewer low-probability plaintiffs would go to trial under the English rule.

But the settlement offer under the English rule generally will not be the same as that under the American rule. Suppose it is lower. ${ }^{6}$ If it is suffciently lower, then even though low-probability plaintiffs are worse off under the English rule if they go to trial, they will be even worse off accepting the settlement offer. Thus, they will reject the offer and go to trial, which implies that the critical probability of prevailing will be lower under the English rule. In other words, some low-probability plaintiffs who would have settled under the American rule will be induced to go to trial under the English rule. This is, in essence, why the settlement process can cause the English rule to result in more low-probability plaintiffs going to trial than the American rule.

The preceding discussion shows that the central issue is how the switch from the American rule to the English rule affects the settlement offer relative to how it affects the value of going to trial. In our formal analysis, we demonstrate that this switch always has the effect of making going to trial relatively more attractive for some low-probability-of-prevailing plaintiffs who would not have gone to trial under the American rule. In other words, the English rule results in more trials by low-probability-of-prevailing plaintiffs regardless of whether the switch to the English rule causes the settlement offer to fall or rise. (The reasoning continues to hold in the latter case because, whenever the settlement offer rises as a result of the switch to the English rule, the expected value of the trial outcome rises by even more for plaintiffs whose probability of prevailing equals the critical probability under the American rule, making trial more attractive to these plaintiffs under the English rule.)

Section II analyzes the American and English rules assuming that settlements are not possible. In Section III we reconsider the rules when the settlement process is taken into account and derive our main results. Section

\footnotetext{
${ }^{5}$ The conclusion that the plaintiff will be worse off at trial under the English rule requires (for reasons not worth explaining here) that the defendant's legal costs are not too much smaller than the plaintiff's legal costs.

${ }^{6}$ It could be higher or lower. See the example in Section IV and comment $c$ in Section V.
} 
IV presents a numerical example that illustrates the points of the earlier sections. And in Section V we conclude with some remarks about the interpretation of our results.

\section{Analysis When All Suits Result in Trial}

In this section we present a model of litigation in which all suits are assumed to result in trial. ${ }^{7}$ We show that the conventional wisdom-that the English rule discourages suits by low-probability plaintiffs more than the American rule-holds in this model under reasonable assumptions.

A risk-neutral injurer engages in conduct that causes harm to one of a number of risk-neutral potential victims. Victims differ in their probability of prevailing at trial. ${ }^{8}$ (We will use the terms "injurer" and "defendant" interchangeably, and similarly for "victim" and "plaintiff.")

If the plaintiff wins at trial, he receives an award from the defendant; if he loses, he pays a penalty to the defendant (which could be zero). Each side bears its own trial costs.

The preceding description of the trial outcome allows the American rule and the English rule to be treated as special cases. Under the American rule, the award is positive and the penalty is zero. Under the English rule, the award is higher by the amount of the plaintiff's trial costs and the penalty equals the defendant's trial costs.

The following notation will be used:

$p=$ probability that the plaintiff will prevail at trial,

$f(p)=$ density of $p$ among potential plaintiffs,

$p_{1}=$ lowest probability of prevailing,

$p_{2}=$ highest probability of prevailing,

$x=$ award paid to the plaintiff by the defendant if the plaintiff prevails at trial,

\footnotetext{
${ }^{7}$ The model used in this section and in Section III is similar to the one in A. Mitchell Polinsky and Daniel L. Rubinfeld, Optimal Awards and Penalties When the Probability of Prevailing Varies among Plaintiffs, 27 RAND J Econ 269 (1996). In our earlier article, it was employed to answer a normative question: What is the optimal award and penalty combination when the objective is to achieve a specified level of deterrence with the least cost in litigation? Here it is used to answer a positive question related to specific institutional practices: Does the English rule discourage low-probability plaintiffs more than the American rule? For further discussion of the relationship between the two articles, see note 18.

${ }^{8}$ The probability might vary because victims differ in their ability to marshall evidence about issues relating to causality or fault. In products liability cases, for example, some victims may have kept packing material or a receipt as proof of purchase, while others may not have.
} 


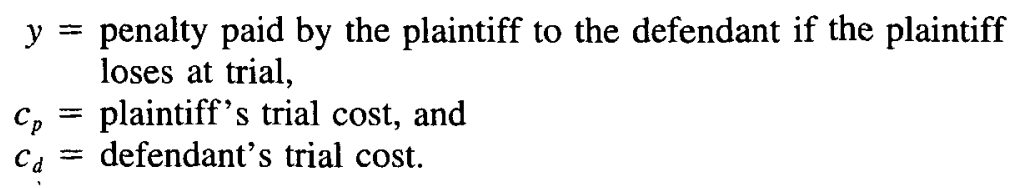

The population of potential plaintiffs is normalized to be unity.

A victim will file a suit (and go to trial) if the expected value of the trial outcome exceeds his trial cost, that is, if

$$
p x-(1-p) y>c_{p} \text {. }
$$

We assume that $x>c_{p}$, so that if the probability of prevailing is sufficiently high, a victim will bring a suit (otherwise a victim would not sue even if he were certain to win). Clearly, if the probability of prevailing is low enough, a victim will not find it worthwhile to sue. Let

$$
\begin{aligned}
\hat{p}(x, y)= & \text { probability of prevailing below which a victim will not sue } \\
& \text { and above which he will sue, }{ }^{9}
\end{aligned}
$$

where $\hat{p}(x, y)$ is defined by

$$
\hat{p} x \dot{-}(1-\hat{p}) y=c_{p} .
$$

Solving for $\hat{p}$ yields

$$
\hat{p}(x, y)=\left(y+c_{p}\right) /(x+y)<1,
$$

where the inequality follows from the assumption that $x>c_{p}$. We will refer to $\hat{p}(x, y)$ as the "critical probability of prevailing."

Now consider the critical probability of prevailing under the American rule and the English rule, which we will denote $\hat{p}_{\mathrm{A}}$ and $\hat{p}_{\mathrm{E}}$. Let $x_{\mathrm{A}}$ and $x_{\mathrm{E}}$ be the awards under the two rules, and let $y_{\mathrm{A}}$ and $y_{\mathrm{E}}$ be the penalties. Under the American rule, $x_{\mathrm{A}}>0$ and $y_{\mathrm{A}}=0$. Under the English rule, $x_{\mathrm{E}}=x_{\mathrm{A}}+$ $c_{p}$ and $y_{\mathrm{E}}=c_{d}$. Hence, from (3),

$$
\hat{p}_{\mathrm{A}}=c_{p} / x_{\mathrm{A}},
$$

and

$$
\hat{p}_{\mathrm{E}}=\left(c_{d}+c_{p}\right) /\left(x_{\mathrm{E}}+c_{d}\right)=\left(c_{d}+c_{p}\right) /\left(x_{\mathrm{A}}+c_{p}+c_{d}\right) .
$$

The conventional wisdom can be characterized as the proposition that the critical probability under the American rule is less than that under the English rule: $\hat{p}_{\mathrm{A}}<\hat{p}_{\mathrm{E}}$. If this condition holds, there will be some relatively

\footnotetext{
${ }^{9}$ Whether a victim whose probability of prevailing is $\hat{p}$ sues does not affect our analysis. (An analogous statement applies to $\tilde{p}$ in Section III.)
} 
low-probability plaintiffs (those between $\hat{p}_{\mathrm{A}}$ and $\hat{p}_{\mathrm{E}}$ ) who will sue under the American rule but not under the English rule.

It is straightforward to show that $\hat{p}_{\mathrm{A}}<\hat{p}_{\mathrm{E}}$ if and only if

$$
\left(c_{p} / c_{d}\right)\left(c_{p}+c_{d}\right)<x_{\mathrm{A}} .
$$

Moreover, if (6) holds, it can be demonstrated that

$$
\hat{p}_{\mathrm{A}}<\hat{p}_{\mathrm{E}}<c_{d} /\left(c_{p}+c_{d}\right)
$$

To understand intuitively whether (6), and therefore (7), is likely to hold, consider the special case in which the plaintiff's and the defendant's trial costs are the same: $c_{p}=c_{d}=c$. Then (6) becomes $2 c<x_{\mathrm{A}}$. If $x_{\mathrm{A}}$, the award to the plaintiff under the American rule, is interpreted as the plaintiff's compensatory damages, then this condition states that the sum of the parties' trial costs is less than the plaintiff's compensatory damages. For most civil litigation this is a reasonable assumption. ${ }^{10}$

Moreover, when the parties' trial costs are the same, (7) becomes $\hat{p}_{\mathrm{A}}<$ $\hat{p}_{\mathrm{E}}<1 / 2$. Thus, the plaintiffs who would sue under the American rule but not under the English rule are plaintiffs whose probability of prevailing is less than one-half.

We will assume that (6) holds, in which case the relationship between the American and the English rules is as described in (7). In other words, in the absence of settlements, the English rule discourages more lowprobability plaintiffs from suing than does the American rule. ${ }^{11}$

${ }^{10}$ On the basis of a series of studies conducted by the Institute for Civil Justice at the RAND Corporation, Deborah R. Hensler et al, Trends in Tort Litigation: The Story behind the Statistics 26 (Publication No R-3583-ICJ, RAND, Inst Civ Justice, 1987), observed that in 1985 aggregate spending on legal fees and expenses ranged from $\$ 6.3$ billion to $\$ 7.5$ billion for plaintiffs and from $\$ 4.7$ billion to $\$ 5.7$ billion for defendants. Together, therefore, the range is from $\$ 11.0$ billion to $\$ 13.2$ billion, which is less than the $\$ 21$ billion to $\$ 25$ billion paid to plaintiffs in total compensation in 1985. (If the preceding numbers are inserted into (6), that condition would hold regardless of whether the low-end or high-end values of the ranges are used.)

"In Bebchuk and Chang's analysis, the English rule also would discourage more lowprobability plaintiffs if a condition equivalent to (6) holds (see Bebchuk and Chang, at n8 (cited at note 1)). In Katz's analysis, the English rule would decrease the proportion of frivolous suits if "the English rule would improve the position of a genuinely injured plaintiff" (see Katz, at 18 (cited at note 1)); in terms of the present notation, this condition can be expressed as $p c_{p}-(1-p) c_{d}>0$, where $p$ is interpreted as the probability of prevailing of a legitimate plaintiff - one who truly was injured. Using the numbers from the previous footnote (either the low-end or the high-end values of the ranges), this condition would hold provided that a legitimate plaintiff has a probability of prevailing of at least .43 . Since there are only two types of plaintiff in Katz's model-those who were not actually injured and those who were-it seems reasonable to suppose that the latter type of plaintiff would prevail with a probability at least this high. 


\section{Analysis When Settlements Are Possible}

This section reconsiders the analysis of the previous section in a standard model of litigation in which settlements are possible. We show in this model that the English rule results in more low-probability-of-prevailing plaintiffs going to trial than the American rule.

The key feature of the settlement analysis is that there is asymmetric information: Each victim knows his probability of prevailing at trial, but the injurer knows only the distribution of the probabilities among potential victims. $^{12}$

The following sequence of events describes the litigation process. First, the victim decides whether to file a suit. Second, if a suit is filed, the defendant makes a single take-it-or-leave-it settlement offer (which could be zero). ${ }^{13}$ Third, the plaintiff decides whether to accept the defendant's offer or to go to trial. Let

$s=$ settlement offer of the defendant.

Although $s$ is a function of $x$ and $y$ (and hence depends on whether the American or the English rule is applicable), for simplicity we suppress this notation.

Since a plaintiff whose probability of prevailing equals unity would obtain a net benefit of $x-c_{p}$ from going to trial, and all other plaintiffs would obtain less, this is the highest settlement offer the defendant would make. Thus,

$$
0 \leq s \leq x-c_{p}
$$

We assume for simplicity that it is costless to file a suit. ${ }^{14}$ Consequently, a victim will file a suit regardless of his probability of prevailing at trial if

${ }^{12}$ It is common in models of litigation that include settlement as a possible outcome to assume that the defendant has imperfect information about some characteristic of the plaintiff, such as the plaintiff's loss or his probability of prevailing. See, for example, Lucian Arye Bebchuk, Suing Solely to Extract a Settlement Offer, 17 J Legal Stud 437 (1988); Katz (cited at note 1); Gravelle, Efficiency Implications (cited at note 2); and Thomas J. Miceli, Optimal Deterrence of Nuisance Suits by Repeat Defendants, 13 Intl Rev L \& Econ 135 (1993). If the defendant knew each plaintiff's probability of prevailing, allowing for the possibility of settlements would not alter the conclusion of the previous section for the reason discussed in comment $f$ in Section V.

${ }^{13}$ We assume that the defendant (the uninformed party) makes a settlement offer in order to avoid the "signalling" complications that would arise if the plaintiff (the informed party) made a settlement demand - the magnitude of the demand might convey information about the plaintiff's type. For a notable attempt to deal with these complications in the context of studying alternative rules for allocating litigation costs, see Reinganum and Wilde (cited at note 2).

${ }^{14}$ In comment $e$ in Section $\mathrm{V}$, we explain why our results would not be affected in any essential way if there were a filing cost. 
the defendant offers any positive settlement: filing a suit and accepting the settlement offer is preferable to not filing the suit.

If the plaintiff accepts the defendant's settlement offer, he obtains $s$; if he rejects it, his expected payoff at trial is $p x-(1-p) y-c_{p}$. It is obvious that if $p$ is low enough, the plaintiff will accept the settlement offer. Let

$$
\begin{gathered}
\tilde{p}(x, y)=\begin{array}{l}
\text { probability of prevailing below which a plaintiff will accept } \\
\text { the settlement offer and above which he will go to trial, }
\end{array}
\end{gathered}
$$

where $\tilde{p}(x, y)$ is defined by

$$
\tilde{p} x-(1-\tilde{p}) y-c_{p}=s .
$$

Solving for $\tilde{p}$ yields

$$
\tilde{p}(x, y)=\left(s+y+c_{p}\right) /(x+y) \leq 1 ;
$$

the inequality follows from (8). We will refer to $\tilde{p}(x, y)$ as the "critical probability of prevailing." 15

Now consider the defendant's choice of the settlement offer $s$. He will choose $s$ so as to minimize the sum of his expected settlement payments and his expected trial payments:

$$
\int_{p_{1}}^{\bar{p}} s f(p) d p+\int_{\tilde{p}}^{p_{2}}\left[p x-(1-p) y+c_{d}\right] f(p) d p .
$$

We assume that the optimal settlement offer is positive, in which case it is determined implicitly by the following first-order condition:

$$
F(\tilde{p})-f(\tilde{p})\left[\left(c_{p}+c_{d}\right) /(x+y)\right]=0,
$$

where $F(\cdot)$ is the cumulative distribution function of $f(\cdot)$ and $\tilde{p}$ is defined by (10). The settlement offer $s$ appears in (12) through $\tilde{p}$. The second-order condition for the minimization of (11) can be written (after slight simplification) as

$$
f(\tilde{p})-f^{\prime}(\tilde{p})\left[\left(c_{p}+c_{d}\right) /(x+y)\right]>0 .
$$

The preceding framework now can be used to examine how the critical probability $\tilde{p}$ changes as the award $x$ and the penalty $y$ increase, taking into account the defendant's adjustment of the settlement offer $s$.

Because the result regarding the penalty, $y$, is counterintuitive, we present

\footnotetext{
${ }^{15}$ Although this phrase was used to refer to $\hat{p}$ in Section II, it is employed here as well
} since $\tilde{p}$ plays an analogous role and $\hat{p}$ will not be referred to in Section III. 
it first. Totally differentiate (12) with respect to $y$, treating $s$ as a function of $y$, to obtain

$$
\begin{gathered}
(d \tilde{p} / d y)\left\{f(\tilde{p})-f^{\prime}(\tilde{p})\left[\left(c_{p}+c_{d}\right) /(x+y)\right]\right\} \\
+f(\tilde{p})\left[\left(c_{p}+c_{d}\right) /(x+y)^{2}\right]=0 .
\end{gathered}
$$

The last term clearly is positive. The term in braces is positive by the second-order condition (13). Thus, for the left-hand side of (14) to be zero, it must be that

$$
d \tilde{p} / d y<0 .
$$

In other words, raising the penalty on losing plaintiffs causes the critical probability of prevailing to fall, assuming the settlement offer of the defendant adjusts optimally.

This result means that a higher penalty causes more plaintiffs to go to trial and that these additional plaintiffs all have a relatively low probability of prevailing (less than the plaintiffs who went to trial before the penalty was raised). Because raising the penalty disfavors low-probability-ofprevailing plaintiffs relative to high-probability-of-prevailing plaintiffs, it may appear puzzling that more low-probability plaintiffs go to trial. The explanation, as has been emphasized previously, has to do with how the settlement offer adjusts.

To see how $s$ changes, it will be useful to restate (15) with $d \tilde{p} / d y$ written explicitly, using (10):

$$
d \tilde{p} / d y=\left[\left(s^{\prime}+1\right)(x+y)-\left(s+y+c_{p}\right)\right] /(x+y)^{2}<0,
$$

where $s^{\prime}$ represents the partial derivative of the settlement offer with respect to a change in the penalty $y$. Solving (16) for $s^{\prime}$ yields

$$
s^{\prime}<\left(s+c_{p}-x\right) /(x+y)<0
$$

where the second inequality follows from (8) (assuming the settlement offer is not so high that every plaintiff accepts it). In other words, raising the penalty causes the settlement offer to fall. This result is not surprising: a higher penalty makes plaintiffs worse off at trial, so the defendant does not need to offer as much to get them to settle.

For the critical probability to fall, however, it must be that, for the marginal plaintiff (the plaintiff whose probability of prevailing equals the critical probability before the increase in the penalty), the settlement offer falls more than the expected value of going to trial falls. For if this is true, such a plaintiff will now strictly prefer to go to trial, which implies that the new marginal plaintiff will be a plaintiff with a lower probability of prevailing.

The crux of the explanation, therefore, is why, for the marginal plaintiff, 
the settlement offer falls more than the expected value of trial declines. To see why this occurs, suppose the penalty rises and the settlement offer initially falls by an amount exactly equal to the reduction in the expected value of trial for the marginal plaintiff. By construction, therefore, this plaintiff remains indifferent between accepting the settlement offer and going to trial, which means that the critical probability initially does not change.

Now consider the pros and cons, from the defendant's perspective, of lowering the settlement offer by, say, a dollar more. Such a reduction saves a dollar for each plaintiff whose probability of prevailing is below the critical probability (these plaintiffs all accept the settlement offer). Since the critical probability has not changed, this benefit is unaffected as a result of the penalty rising.

But lowering the settlement offer by a dollar induces more plaintiffs to reject the settlement offer and opt for trial; each such plaintiff makes the defendant worse off. ${ }^{16}$ The crucial point is that this cost of lowering the settlement offer has fallen as a result of the penalty rising, for the following reason. The higher the penalty from losing at trial, the greater the reduction in the expected value of trial for a plaintiff whose probability of prevailing is a specified amount below the marginal plaintiff's probability of prevailing. Consequently, given a dollar reduction in the settlement, some plaintiffs whose probability of prevailing is below the marginal plaintiff's probability of prevailing will now opt for the settlement rather than go to trial. In other words, fewer additional plaintiffs will sue the defendant if the defendant lowers the settlement offer by a dollar, which means that the cost to the defendant of doing this is less than it was before the penalty was raised.

In summary, suppose the penalty rises and the settlement offer falls to a level that leaves the critical probability unchanged. Starting from this level, the benefit of lowering the settlement offer further is the same as before the penalty rose. But the cost of lowering the settlement offer further is lower as a result of the penalty rising. Hence, it is optimal for the defendant to lower the settlement offer further, which implies that the critical probability of prevailing declines-the result formally demonstrated above.

The analysis of how the critical probability of prevailing $\tilde{p}$ is affected by raising the award, $x$, closely parallels the analysis just completed. Totally differentiating (12) with respect to $x$, treating $s$ as a function of $x$, results in

${ }^{16}$ If the marginal plaintiff goes to trial, the expected cost to the defendant is $\tilde{p} x-$ $(1-\tilde{p}) y+c_{d}$. If instead the plaintiff accepts the settlement offer, the cost to the defendant is, by (9), $\tilde{p} x-(1-\tilde{p}) y-c_{p}$. Hence, if the marginal plaintiff goes to trial, the defendant is worse off by $c_{d}+c_{p}$. 
an expression virtually identical to (14) (the only difference is that $d \tilde{p} / d x$ is substituted for $d \tilde{p} / d y$ ), from which it follows that

$$
d \tilde{p} / d x<0 \text {. }
$$

In other words, when the settlement offer of the defendant adjusts optimally, raising the award to winning plaintiffs causes the critical probability of prevailing to fall.

The intuition behind this result is analogous to that given above. A higher award makes plaintiffs better off at trial. Suppose the defendant raises the settlement offer so that, for the marginal plaintiff (the plaintiff whose probability of prevailing equals the critical probability before the increase in the award), the settlement offer continues to equal the expected value of going to trial. By construction, the critical probability will not have changed.

Lowering the settlement offer from this level by a dollar saves the defendant a dollar for each plaintiff whose probability of prevailing is below the critical probability. Since the critical probability has not changed, this benefit is unaffected as a result of the award rising.

But lowering the settlement offer by a dollar induces more plaintiffs to opt for trial. The key point is that this cost of lowering the settlement offer has fallen as a result of the award rising: The higher the award from winning at trial, the greater the reduction in the expected value of trial for a plaintiff whose probability of prevailing is a specified amount below the marginal plaintiff's probability of prevailing. Consequently, given a dollar reduction in the settlement, some plaintiffs whose probability of prevailing is below the marginal plaintiff's probability of prevailing will now opt for the settlement rather than go to trial. In other words, fewer additional plaintiffs will sue the defendant if the defendant lowers the settlement offer by a dollar, which means that the cost to the defendant of doing this is less than it was before the award was raised.

Since the marginal benefit of lowering the settlement offer is the same as before, but the marginal cost is lower, it is optimal for the defendant to lower the settlement offer, which implies that the critical probability of prevailing declines.

The application of the preceding results to the question of whether the English rule results in fewer trials by low-probability plaintiffs than the American rule is straightforward. As observed in Section II, the English rule can be characterized as increasing both the award-by the plaintiff's trial costs - and the penalty - by the defendant's trial costs. We have demonstrated that both effects lower the critical probability of prevailing when the settlement process is taken into account. Hence, the critical probability will be lower under the English rule, meaning that the English rule causes more plaintiffs to go to trial and that these additional plaintiffs are all ones 
whose probability of prevailing is relatively low-less than the lowestprobability-of-prevailing plaintiff who goes to trial under the American rule. ${ }^{17}$ It is in this sense that the English rule encourages low-probabilityof-prevailing plaintiffs more than the American rule. ${ }^{18}$

Note also that the same suits are filed under the two rules in our analysis. This follows from assumptions, stated previously, that apply under both rules-the settlement offer is positive, and there is no cost to filing a suit. ${ }^{19}$ Thus, regardless of which rule governs, a victim will file a suit. ${ }^{20}$

\section{A NumERICAL EXAMPLE}

To illustrate the results in Sections II and III, we present a numerical example in which the density of the probability of prevailing is uniform between .1 and .9 and each party's trial cost is $\$ 2,500$. Under the American rule, the award is assumed to be $\$ 15,000$. Under the English rule, the corresponding award is $\$ 17,500$ ( $\$ 15,000$ plus the plaintiff's trial cost), and the penalty is $\$ 2,500$ (the defendant's trial cost).

17 This result is worth contrasting with an analogous result in Bebchuk, Litigation and Settlement (cited at note 2). In his model, unlike ours, defendants differ in type (their probability of being found liable at trial), and the plaintiff makes a take-it-or-leave-it settlement demand (knowing only the distribution of defendant types). His proposition 6 shows that there will be a greater number of trials under the English rule, a conclusion with which we agree. Although he did not spell out what his analysis implies about which additional defendants go to trial, it is clear from his model that they are defendants whose probability of being found liable is relatively high. In other words, in his analysis the additional trials under the English rule are those in which plaintiffs have a relatively high probability of prevailing, the opposite of our result.

18 This conclusion might appear to be at odds with our analysis in Polinsky and Rubinfeld (cited at note 7), where we demonstrated that if the award to winning plaintiffs and the penalty on losing plaintiffs can be set sufficiently high, low-probability-of-prevailing plaintiffs can be discouraged from suing (without reducing the deterrence of the defendant). The two conclusions are consistent, however. In the example used to illustrate the result in the earlier article, raising the award and the penalty initially lowers the optimal settlement offer of the defendant and induces some low-probability plaintiffs to go to trial who otherwise would have accepted the settlement offer. This reflects the point that we have been emphasizing here. Eventually, however, the defendant's settlement offer falls to zero, after which further increases in the award and penalty discourage low-probability potential plaintiffs from suing. In our present analysis, we have assumed that the defendant's settlement offer is positive, in which case the limiting result demonstrated in the earlier article is not applicable. This assumption is reasonable since switching from the American rule to the English rule raises the award and the penalty by a fixed amount (the plaintiff's trial cost and the defendant's trial cost, respectively).

${ }_{19}$ As observed in note 14, the assumption of a zero filing cost is not essential.

20 The fact that the same cases are filed under the two rules in our model is not necessary to our result. For even if (in a different model) the English rule were to discourage more low-probability plaintiffs from filing suit, the critical probability determining which plaintiffs go to trial and which settle could fall under the English rule for the reasons we have explained. See note 29. 
If all suits result in trial, the critical probability of prevailing is .17 under the American rule and .25 under the English rule. ${ }^{21}$ This implies that the English rule reduces the number of suits, and therefore trials, by 11 percent, ${ }^{22}$ and this reduction comes about by discouraging low-probability-ofprevailing plaintiffs-those with probabilities of prevailing between .17 and .25 .

If, however, the settlement process is taken into account, the critical probability of prevailing is .43 under the American rule and .35 under the English rule. ${ }^{23}$ Now the English rule increases the number of trials by 18 percent, ${ }^{24}$ and this increase is due to encouraging relatively low-probabilityof-prevailing plaintiffs to go to trial-those with probabilities of prevailing between .35 and .43 .

To see how much the English rule augments the incentive to go to trial in the example, consider the marginal plaintiff under the American rule, whose probability of prevailing is .43 . Switching to the English rule reduces the expected value of trial for this plaintiff by $\$ 334$ (from $\$ 4,000$ under the American rule to $\$ 3,666$ under the English rule), ${ }^{25}$ which makes going to trial less attractive for this plaintiff. But the defendant's optimal settlement offer declines by $\$ 2,000$ (from $\$ 4,000$ under the American rule to $\$ 2,000$ under the English rule), ${ }^{26}$ which makes accepting the settlement offer even less attractive. Hence, this plaintiff, who under the American rule was indifferent between accepting the settlement offer and going to trial, now strongly prefers to go to trial under the English rule.

21 This follows immediately from (3) with $x=\$ 15,000$ and $y=\$ 0$ under the American rule, and $x=\$ 17,500$ and $y=\$ 2,500$ under the English rule. The critical probability under the American rule that is reported in the text is rounded to the nearest hundredth; the unrounded value of this probability is $\$ 2,500 / \$ 15,000=.166666 \ldots$.

22 Under the American rule, the fraction of potential plaintiffs who sue is (.9 $.1667) /(.9-.1)=.9166$; under the English rule the corresponding fraction is $(.9-$ $.25) /(.9-.1)=.8125$. Hence, there are 11.36 percent fewer trials under the English rule $(=[(.9166-.8125) / .9166] \times 100 \%)$.

${ }^{23}$ The optimal settlement offer of the defendant can be derived from (12) using the assumption that $f(p)$ is uniform between .1 and .9 and that each party's trial cost is $\$ 2,500$. The result is $s=\$ 2,500+.1 x-.9 y$. Under the American rule, with $x=\$ 15,000$ and $y=$ $\$ 0$, the defendant's settlement offer is $\$ 4,000$. Under the English rule, with $x=\$ 17,500$ and $y=\$ 2,500$, the settlement offer is $\$ 2,000$. Substituting these values into (10) yields the critical probabilities reported in the text. The unrounded value of the critical probability under the American rule is $\$ 6,500 / \$ 15,000=.433333$. . .

24 Under the American rule, the fraction of potential plaintiffs who go to trial is (.9 $.4333) /(.9-.1)=.5834$; under the English rule, the corresponding fraction is $(.9-$ $.35) /(.9-.1)=.6875$. Hence, there are 17.84 percent more trials under the English rule $(=[(.6875-.5834) / .5834] \times 100 \%)$.

${ }^{25}$ These numbers correspond, respectively, to $.4333(\$ 15,000)-\$ 2,500$ and $.4333(\$ 17,500)-(1-.4333)(\$ 2,500)-\$ 2,500$.

${ }^{26}$ See note 23. 


\section{CONCLUding Remarks}

We conclude with several remarks concerning the interpretation of our results.

a) It is well known that the English rule makes low-probability plaintiffs worse off at trial than does the American rule. ${ }^{27}$ The point we have been emphasizing - that the English rule leads to more trials by low-probability plaintiffs - is not inconsistent with this fact. For instance, in the numerical example in the previous section, the marginal plaintiff under the American rule-whose probability of prevailing was .43 - was worse off under the English rule by $\$ 334$ if he went to trial. Yet this plaintiff had a stronger incentive to go to trial under the English rule than under the American rule. As explained previously, this is because the switch to the English rule caused the settlement offer to fall by more than the expected value of going to trial declined. Thus, a low-probability plaintiff could be worse off at trial under the English rule yet have a stronger incentive to go to trial.

b) In general, some of the low-probability plaintiffs who would be made worse off at trial under the English rule might not file suit as a result. ${ }^{28}$ This is, of course, the conventional point about the English rule in relation to the American rule. However, it still could be true that, for those plaintiffs who do file suit, the critical probability determining which plaintiffs go to trial and which settle falls under the English rule for the reasons we have explained. Thus, there is no necessary inconsistency between the conventional result that the English rule discourages low-probability plaintiffs from filing suits and our conclusion that the English rule leads to a greater number of low-probability plaintiffs going to trial. ${ }^{29}$

c) In explaining the intuition behind our results, we have focused on the case in which the defendant's settlement offer is lower under the English

\footnotetext{
27 This conclusion is implicit in the passages quoted from Shavell (cited at note 1) and Rosenberg and Shavell (cited at note 1).

${ }^{28}$ For the reason given at the end of Section III, this effect does not arise in our formal analysis.

${ }^{29}$ The following reasoning shows why this statement is correct. Suppose in our model that the settlement offer under the English rule, $s_{\mathrm{E}}$, is less than the settlement offer under the American rule, $s_{\mathrm{A}}$. (We know from the numerical example in Section IV that this can occur.) Now assume that a small fraction of potential victims would incur filing costs. If this fraction is small enough, the behavior of these potential victims will have a negligible effect on the outcome. For simplicity, let there be only one such potential victim and assume that his filing cost, $f$, is such that $s_{\mathrm{E}}<f<s_{\mathrm{A}}$. Suppose further that this potential victim's probability of prevailing, $p^{\circ}$, is less than the critical probability under the English rule, $\tilde{p}_{\mathrm{E}}$, which we know is less than the critical probability under the American rule, $\tilde{p}_{\mathrm{A}}$; in other words, $p^{\circ}<\tilde{p}_{\mathrm{E}}<$ $\tilde{p}_{\mathrm{A}}$. Under the American rule, therefore, this potential victim will file a suit and accept the settlement offer. But under the English rule, he will not file a suit. In all other respects, the outcome is identical-including that the English rule leads to more low-probability plaintiffs going to trial.
} 
rule than under the American rule. It is worth noting, however, that our central point does not depend on the settlement offer decreasing. In Section III, the formal demonstration that the critical probability of prevailing declines when the award and/or the penalty rises presumed only that the settlement offer adjusted optimally, not that it was lower. Indeed, switching to the English rule could cause the settlement offer to rise. For instance, in the example in Section IV, it can be demonstrated that the settlement offer would be higher under the English rule if the lower bound of the distribution of the probability of prevailing exceeds one-half. ${ }^{30}$ The intuitive explanation of why the critical probability of prevailing still would fall under the English rule is as follows: If the lowest probability of prevailing exceeds one-half, then the marginal plaintiff under the American rule must be a plaintiff whose probability of prevailing exceeds one-half. Hence, switching to the English rule makes this plaintiff better off. Even though the optimal settlement offer is higher under the English rule (given our current assumption about the lowest probability of prevailing), it will not rise as much as the expected value of going to trial rises for this plaintiff. ${ }^{31}$ Consequently, this plaintiff will strictly prefer to go to trial under the English rule, whereas he was (by definition) indifferent between accepting the settlement offer and going to trial under the American rule. This implies that the critical probability of prevailing will be lower under the English rule.

d) Even though switching to the English rule makes plaintiffs whose probability of prevailing is below some threshold worse off if they go to trial, the English rule actually could result in many of these plaintiffs being made better off if they accept the defendant's settlement offer. To see why, suppose the settlement offer under the English rule is higher than that under the American rule. Every plaintiff whose probability of prevailing is below the critical probability under the English rule will accept the settlement of-

\footnotetext{
${ }^{30}$ Other theoretical studies of the allocation of legal fees also have observed that the settlement amount could be higher or lower under the English rule. See Reinganum and Wilde, at 564 (cited at note 2); Coursey and Stanley, at 164-65 (cited at note 2); Gravelle, Accidents, at 19 (cited at note 2); and Bebchuk, The Effect of Fee-Shifting Rules, at 10-11 (cited at note 2). In Png's model, Png, Litigation (cited at note 2), the settlement offer is higher under the English rule (compare his propositions 1 and 4). Gravelle, Efficiency Implications (cited at note 2), provides sufficient conditions for the settlement offer to be higher under the English rule (see his proposition 1). Also, in Hughes and Snyder's, at 243 (cited at note 1), empirical study of medical malpractice claims in Florida, they found that "settlements under the English rule tend to be higher." But Gary M. Fournier and Thomas W. Zuehlke, Litigation and Settlement: An Empirical Approach, 71 Rev Econ \& Stat 189 (1989), in an empirical study of civil cases in federal courts, found that switching to the English rule causes the settlement to fall (although this result was only marginally statistically significant).

${ }^{31}$ The explanation of why the settlement offer does not rise as much as the expected value of going to trial rises is analogous to the explanation in Section III of why the critical probability of prevailing declines when the award rises.
} 
fer under both rules; so if the settlement offer is higher under the English rule, these plaintiffs will be better off under that rule. Note, moreover, that it will be the plaintiffs with the lowest probabilities of prevailing who will accept the settlement offer. Thus, the English rule could have the paradoxical effect of making one group of plaintiffs with relatively low probabilities of prevailing worse off than under the American rule (those in the range between the critical probabilities under the two rules, who go to trial under the English rule), yet make plaintiffs with even lower probabilities better off (those in the range below the critical probability under the English rule, who will accept the higher settlement offer under the English rule).

e) Our analysis assumed that no cost is incurred simply from filing a suit. If there is a filing cost, and this cost is the same for all plaintiffs, our results are not affected in any essential way. The main difference is that any settlement offer by the defendant that is lower than the plaintiffs' filing cost is equivalent to a settlement offer of zero, since no plaintiff would file a suit in order to obtain a settlement offer less than his filing cost. If the settlement offer exceeds the plaintiffs' filing cost, then every plaintiff will file a suit either to obtain the settlement offer or to do even better by going to trial. Thus, assuming that a nontrivial settlement offer is made-one that is acceptable to at least some plaintiffs-every plaintiff will file a suit, and the relationship between the American rule and the English rule will be as we have described. ${ }^{32}$

$f$ ) Finally, it is worth noting that the settlement process would not affect the conventional wisdom about the American and English rules if the defendant knows each plaintiff's probability of prevailing. Then his settlement offer to a plaintiff would equal that plaintiff's expected value of going to trial (less the plaintiff's trial cost). Hence, if the English rule reduces a plaintiff's expected value of trial, the settlement offer to that plaintiff will decline by the same amount, which means that his decision about whether to go to trial or accept a settlement offer will not be affected. Under the present assumption about the defendant's information, therefore, the English rule would not increase the incentive of low-probability plaintiffs to go to trial. Rather, it would have the conventional effect of discouraging low-probability plaintiffs from suing. ${ }^{33}$ However, if, more realistically, the defendant does not know each plaintiff's probability of prevailing, then switching to the English rule could cause more low-probability plaintiffs to go to trial for the reasons we have explained.

32 One point worth noting, however, is that the greater the filing cost, the stronger the incentive for the defendant to make a settlement offer of zero; this is because any settlement offer, to be accepted, must exceed the filing cost and hence is more costly to the defendant the higher the filing cost.

${ }^{33}$ This is, in effect, what Rosenberg and Shavell (cited at note 1) demonstrate. 
HeinOnline -- 27 J. Legal Stud. 5361998 